\title{
Challenges of declarative modeling of conductance-based neurons in diverse simulation environments
}

\author{
Ivan Raikov ${ }^{1,2^{*}}$, Thomas G Close ${ }^{1}$, Shyam Kumar $S^{2}$, Erik De Schutter ${ }^{1,2}$ \\ From Twenty Second Annual Computational Neuroscience Meeting: CNS*2013 \\ Paris, France. 13-18 July 2013
}

There exist several declarative computer languages for describing computational neuroscience models. NeuroML[1] encompasses ion channels, cell morphology, and networks, NineML[2] is focused on hybrid spiking neurons, and SBML[3] has been successfully used to describe ion channel kinetics. However, despite the existence of these standards, only a handful of complex conductance-based neuronal models have been ported to a simulator-independent declarative formats, and even then they have been tested and used only in relatively similar cable equation solvers such as NEURON[4]. The present study is an attempt to answer the question whether several widely used models can be ported to a declarative language and used in diverse simulation environments such as NEST[5], a point neuron oriented simulator, or general-purpose numerical environments such as GNU Octave[6].

We present the results of our work on porting several complex conductance-based neuronal models to a prototype layer-oriented declarative model description language [7]. The types of cells included in the study are Purkinje cell [8], Golgi cell [9], cerebellar granule cell [10], CA1 and CA3 pyramidal cell $[11,12]$. The models chosen are among or derived from the 30 most frequently downloaded models from ModelDB [13] ( $\mathrm{T}$ Morse: Personal Communication). The study involves the simulation of current injection and voltage clamp under NEURON, NEST and Octave and quantifying the existing differences in voltage and current traces. In cases where the original model is multi-compartmental, only a single-compartment soma variant is considered.

\footnotetext{
* Correspondence: raikov@oist.jp

'Computational Neuroscience Unit, Okinawa Institute of Science and Technology, Okinawa, Japan

Full list of author information is available at the end of the article
}

In the study, we attempt to quantify some of the important differences that exist between simulators, and we present a code generation approach that can solve the challenges caused by these differences. Furthermore, we highlight practical issues encountered while developing a convenient Python wrapper class for model code generated from the prototype language. This work is a step towards establishing a significant body of declarative models of neurons and identifies some of the issues related to interoperability of diverse neuroscience software.

\section{Author details}

Computational Neuroscience Unit, Okinawa Institute of Science and Technology, Okinawa, Japan. ' University of Antwerp, Antwerp, Belgium.

Published: 8 July 2013

\section{References}

1. Gleeson P, Crook S, Cannon R, Hines M, Billings G, Farinella M, Morse T, Davidson A, Ray S, Bhalla U, Barnes S, Dimitrova Y, Silver A: NeuroML: A Language for Describing Data Driven Models of Neurons and Networks with a High Degree of Biological Detail. PLoS Comp Biol 2010, 6(6): e1000815

2. [http://software.incf.org/software/nineml].

3. Hucka M, Finney A, Sauro H, Bolouri H, Doyle J, Kitano H, Arkin A, Bornstein B, Bray D, Cornish-Bowden A, Cuellar A, Drovnov S, Gilles E, Ginkel M, Gor V, Goryanin I, Hedley W, Hodgman T, Hofmeyer J, Hunter P, Juty N, Kasberger J, Kremling A, Kummer U, Le Novère N, Loew L, Lucio D, Mendes P, Minch E, Mjolsness $E$, et al: The Systems Biology Markup Language (SBML). Bioinform 2003, 19(4):524-531.

4. Carnevale NT, Hines M: The NEURON Book. Cambridge, UK: Cambridge University Press; 2006.

5. Gewaltig M-O, Diesmann M: NEST (NEural Simulation Tool). Scholarpedia 2007, 2(4)

6. [http://www.gnu.org/software/octave/].

7. Raikov I, De Schutter E: The layer-oriented approach to declarative languages for biological modeling. PLoS Comp Biol 2012, 8(5):e1002521.

8. Khaliq ZM, Gouwens NW, Raman IM: The contribution of resurgent sodium current to high-frequency firing in Purkinje neurons: an experimental and modeling study. Journal of Neuroscience 2003, 23(12).
C Biomed Central

C 2013 Raikov et al; licensee BioMed Central Ltd. This is an Open Access article distributed under the terms of the Creative Commons Attribution License (http://creativecommons.org/licenses/by/2.0), which permits unrestricted use, distribution, and reproduction in any medium, provided the original work is properly cited. 
9. Simoes de Souza FM, De Schutter E: Robustness effect of gap junctions between Golgi cells on cerebellar cortex oscillations. Neural Systems \& Circuits 2011, 1:7.

10. Diwakar S, Magistretti J, Goldfarb M, Naldi G, D'Angelo E: Axonal Na+ Channels Ensure Fast Spike Activation and Back-Propagation in Cerebellar Granule Cells. J Neurophysiol 2009, 101(2):519-532.

11. Hemond P, Epstein D, Boley A, Migliore M, Ascoli G, Jaffe D: Distinct classes of pyramidal cells exhibit mutually exclusive firing patterns in hippocampal area CA3b. Hippocampus 2008, 18(4):411-424.

12. Royeck M, Horstmann MT, Remy S, Reitze M, Yaari Y, Beck H: Role of Axonal NaV1.6 Sodium Channels in Action Potential Initiation of CA1 Pyramidal Neurons. J Neurophysiol 2008, 100(4):2361-2380.

13. Hines ML, Morse T, Migliore M, Carnevale N, Shepherd G: ModelDB: A Database to Support Computational Neuroscience. J Comput Neurosci 2004, 17(1):7-11

doi:10.1186/1471-2202-14-S1-P94

Cite this article as: Raikov et al:: Challenges of declarative modeling of conductance-based neurons in diverse simulation environments. $B M C$ Neuroscience 2013 14(Suppl 1):P94.

\section{Submit your next manuscript to BioMed Central} and take full advantage of:

- Convenient online submission

- Thorough peer review

- No space constraints or color figure charges

- Immediate publication on acceptance

- Inclusion in PubMed, CAS, Scopus and Google Scholar

- Research which is freely available for redistribution

Submit your manuscript at www.biomedcentral.com/submit
Ciomed Central 